\title{
Editorial da Direcção
}

Porquê a criação da Revista ADSO?

Porque era uma velha aspiração da Associação dos Docentes e Orientadores de Medicina Geral e Familiar (ADSO) expressa no ponto 7. do artigo 4. ${ }^{\circ}$ dos seus Estatutos, aprovados em 2001: "Produzir relatórios e publicar livros, revistas ou jornais relevantes para a formação em MGF".

A ADSO teve o seu nascimento em Albufeira aquando da realização do Seminário Residencial para Orientadores de Formação do Internato Complementar de Clínica Geral da Zona Sul a 5 de novembro de 2000. Foi sua principal impulsionadora a Prof. ${ }^{a}$ Doutora Maria Isabel Santos que conjuntamente com o Dr. Luís Filipe Gomes e o Dr. Carlos Príncipe Ceia constituíram o grupo Pro-ADSO. A estes se juntou posteriormente a Dr. ${ }^{a}$ Assunção Martinez.

A primeira reunião explicativa dos objetivos e estratégias da ADSO teve lugar em Vilamoura a 17 de março de 2001 aquando do $18^{\circ}$ Encontro Nacional de Clínica Geral. Nesta reunião estiveram presentes 84 médicos de família ligados à formação em Medicina Geral e Familiar nas suas várias vertentes, ficando desde logo todos incluídos como associados fundadores da ADSO.

Foi constituído um grupo de trabalho que se encarregaria de elaborar os estatutos, marcar a escritura de constituição bem como a primeira Assembleia Geral para eleição dos Corpos Sociais, em que intervieram a Prof. ${ }^{a}$ Doutora Maria Isabel Santos, a Dr. ${ }^{a}$ Assunção Martinez, a Dr. ${ }^{a}$ Conceição Outeirinho, a Dr. ${ }^{a}$ Fernanda Raposo, o Dr. Carlos Príncipe Ceia, o Dr. Luís Filipe Gomes, o Dr. Vasco Queiróz e o Dr. José Augusto Simões.

A ADSO foi formalmente constituída por escritura no Cartório Notarial de Monchique a 20 de junho de 2001 tendo a sua primeira Assembleia Geral, com eleição dos Corpos Sociais, decorrido em Coimbra no dia 19 de outubro de 2001 a par das XVI Jornadas de MGF de Coimbra.

Foi primeiro Presidente da direção o Prof. Doutor José Guilherme Jordão, que logo dinamizou a criação de um espaço ADSO na Revista Portuguesa de Clínica Geral mediante a publicação de um artigo bimestral.

Assim a Revista da ADSO deve refletir, em particular, o trabalho desempenhado pelos seus membros na sua ação dedicada ao ensino e formação da prática da Medicina Geral e Familiar (MGF), quer no pré quer no pós-graduado.

Um conjunto de valores e de vontades associou-se para que fosse possível o lançamento deste projeto e quero exprimir o meu agradecimento ao Prof. Doutor Luiz Miguel Santiago pelo empenho na sua concretização.

Quero também agradecer o apoio concedido pela Merck Sharp \& Dohme (MSD Portugal), neste aspeto da maior relevância, pois foi dado sem pedir nada em troca, que não a publicitação do seu suporte. 